Research Article

\title{
Impact of Wall Configurations on Seismic Fragility of Steel-Sheathed Cold-Formed Steel-Framed Buildings
}

\author{
Liqiang Jiang $\mathbb{D}^{1}$ and Jihong $\mathrm{Ye} \mathbb{i}^{1,2}$ \\ ${ }^{1}$ The Key Laboratory of Concrete and Prestressed Concrete Structures of the Ministry of Education, Southeast University, Nanjing, \\ Jiangsu 210018, China \\ ${ }^{2}$ State Key Laboratory for Geomechanics and Deep Underground Engineering, China University of Mining and Technology, \\ Xuzhou, Jiangsu 211116, China \\ Correspondence should be addressed to Jihong Ye; yejihong@seu.edu.cn
}

Received 8 August 2017; Accepted 24 October 2017; Published 19 February 2018

Academic Editor: Dimitris Rizos

Copyright (c) 2018 Liqiang Jiang and Jihong Ye. This is an open access article distributed under the Creative Commons Attribution License, which permits unrestricted use, distribution, and reproduction in any medium, provided the original work is properly cited.

\begin{abstract}
Seismic fragility of steel-sheathed cold-formed steel-framed (CFSF) structures is scarcely investigated; thus, the information for estimation of seismic losses of the steel-sheathed CFSF buildings is insufficient. This study aims to investigate the seismic fragility of steel-sheathed CFSF buildings with different wall configurations. Analytic models for four 2-story steel-sheathed CFSF buildings are established based on shaking table tests on steel-sheathed CFS walls. Then, a group of fragility curves for these buildings are generated. The results show that the thickness of steel sheathing and the fastener spacing of the wall have significant impact on seismic fragility of steel-sheathed CFSF buildings. The seismic fragility of the CFSF building can be reduced by increasing the thickness of steel sheathing or decreasing the fastener spacing. By increasing the thickness of steel sheathing, the reduction on probability is more obvious for the CP limit. It is also found that the exceeding probability is approximately linear with fastener spacing, with a slope in the range from $0.25 \% / \mathrm{mm}$ to $0.50 \% / \mathrm{mm}$.
\end{abstract}

\section{Introduction}

Cold-formed steel (CFS) structure is one of the most popular used building systems for single-family and multi-family residential buildings. According to the previous study conducted by Ye et al. [1], the role of the sheathing wall is the critical part for lateral resistance of CFSF buildings. Thus, to improve the seismic performance of CFSF structures, various types of wall sheathing were introduced and investigated [2-6], and the steel-sheathed CFSF wall is one of them. Yu and his colleagues $[7,8]$ conducted experimental investigations on steel-sheathed CFSF walls in different thicknesses of steel sheathing with $4: 3$ aspect ratio. Experimental studies were carried out by Rogers and his colleagues [9-11] to develop Canadian seismic design provisions for steel-sheathed CFSF walls. Shaking table tests on 10 steel-sheathed CFSF walls and numerical investigations on these specimens were conducted by Rogers and his colleagues [12-14]. Capacity reduction factors of the steel-sheathed CFSF walls were studied by Shakibanasab et al. [15], and cyclic tests on 6 steel-sheathed CFSF walls with one- and two- sided sheathing were conducted by Attari et al. [16]. A total of 24 full-scale steel-sheathed CFSF walls with various configurations in studs and screws were tested by Javaheri-Tafti et al. [17]. The effects of different sizes of CFS frames and different thicknesses of steel sheathing on steel-sheathed CFSF walls were investigated by Mohebbi et al. [18] using 6 specimens. Numerical modeling method for steel-sheathed CFSF walls was proposed by Niari et al. [19], and this method was verified by the test results. The steel sheathing increased the lateral resistance and ductility of the CFSF structures according to the conclusions drawn by these above references, and this structural system was also approved by AISI 400-15 [20].

During the past decades, communicating and reducing the seismic hazard of building structures have become a hot topic in the field of civil engineering. Many researchers stated that the structures need to have enough confidence to resist the earthquakes, and the damages are also need to be reduced to an acceptable level when these structures experience an earthquake. Seismic fragility analysis was proposed as an efficient tool for probabilistic estimation of the 
Bold lines are steel-sheathed shear walls

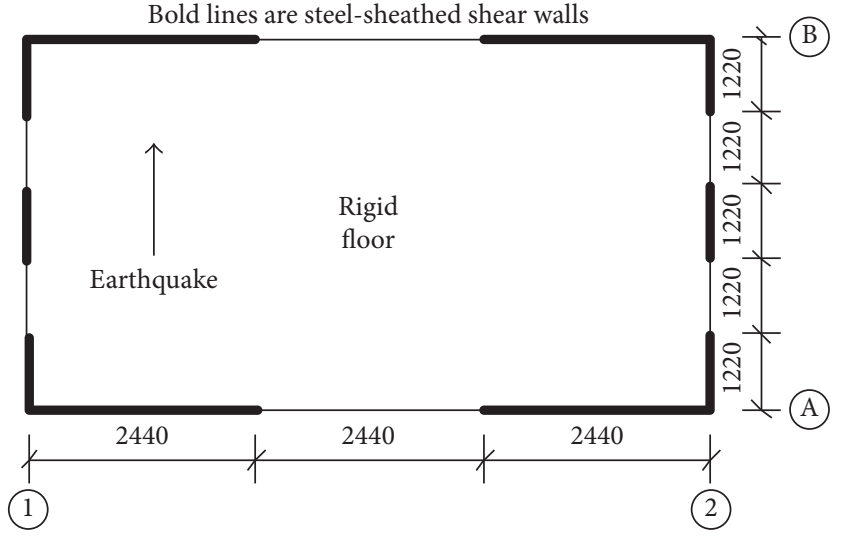

Figure 1: Plan view of a 2-story steel-sheathed CFSF building.

seismic losses, and it was also used by the designers to make decisions for seismic risk reduction. Seismic fragility analyses have been performed on RC, steel, masonry, historical buildings [21-24], etc. With the same requirements for CFSF buildings, many researchers are making efforts to quantify their seismic fragility. Experimental and numerical investigations have been conducted to examine the dynamic performance of CFSF buildings and to generate the fragility functions. Shaking table tests of a full-scale CFS building with the discussion of the seismic responses were conducted by Schafer and his colleagues $[25,26]$. Shaking table test on a full-scale CFS partition wall infilled steel frame building was performed by Wang et al. [27], and fragility curves were generated for these CFS partition walls. Another study aimed to propose the performance limits of CFS partition walls and generated the fragility functions of these walls based on shaking table tests [28]. Seismic fragility of CFS gypsum partition walls was created according to statistic analyses on monotonic and cyclic test results [29].

However, very few studies have been conducted to investigate the seismic fragility of steel-sheathed CFSF buildings, especially for the influences on different wall configurations. In this paper, the impact of wall configurations on seismic fragility was investigated by studies on four 2-story steel-sheathed CFSF buildings. Firstly, the analytic model of these buildings was established and validated based on the shaking table tests of steel-sheathed CFSF walls. Then, 20 ground motions derived from SAC project were used to perform incremental dynamic analyses (IDA) of these buildings. Besides, the performance limits of these buildings were defined based on the failure mechanism and test results of previous studies. Lastly, the effects of sheathing thickness and fastener spacing on seismic fragility of steel-sheathed CFSF buildings were discussed.

\section{Representative Steel-Sheathed CFSF Building Structure}

Most CFSF buildings are constructed as one-story or twostory in the United States; thus, a 2-story steel-sheathed CFSF building at Los Angeles in the United States is chosen as a target structure. Such buildings comprise steel-sheathed CFSF walls, a roof, and a floor. The roof and the floor are considered to be rigid panels. The steel-sheathed CFSF walls are designed with a dimension of $1.22 \mathrm{~m}$ width $\times 2.44 \mathrm{~m}$ height. A plan view on layout of the steel-sheathed walls is shown in Figure 1. The total height of the building is $5.88 \mathrm{~m}$, which can be divided as $2.74 \mathrm{~m}$ for the first story and $2.44 \mathrm{~m}$ for the second story, respectively. A rigid-assumed floor with $0.3 \mathrm{~m}$ thickness is constructed between the first and second story. Four CFS beams are placed between the walls of the first story and the second story. The dead loads are $2.92 \mathrm{kN} / \mathrm{m}^{2}$ and $2.23 \mathrm{kN} / \mathrm{m}^{2}$ for the floor and roof, respectively, while the live loads are $1.92 \mathrm{kN} / \mathrm{m}^{2}$ and $1.44 \mathrm{kN} / \mathrm{m}^{2}$ for the floor and roof, respectively. The direction of the inputted ground motions is illustrated in Figure 1.

In Figure 1, the bold lines represent steel-sheathed CFS walls, and a single type of wall is used in the building. Totally, four types of steel-sheathed CFS walls with different configurations are investigated in this paper, and the details of these walls are shown in Table 1 . These walls were $1.22 \mathrm{~m}$ in width and $2.44 \mathrm{~m}$ in height (with $2: 1$ aspect ratio) and were sheathed with steel sheathing at one side. The cold-formed steel was used by ASTM A653 grade steel. To investigate the impact of wall configurations on seismic behavior of CFSF walls, parameters such as sheathing thickness and fastener spacing are chosen, and these parameters presented significant influence on the performance of CFSF walls [12, 13]. The impact of fastener spacing on the performance of CFSF walls was investigated by comparing the S-2, S-3, and S-4 by changing the spacing from $150 \mathrm{~mm}$ to $75 \mathrm{~mm}$. The impact of sheathing thickness on the performance of CFSF walls was investigated by comparing S-1 with S-4 by changing the thickness from $0.46 \mathrm{~mm}$ to $0.76 \mathrm{~mm}$. The Rayleigh damping is used in the dynamic analyses of this paper, and such values of these buildings are determined by the shaking table tests $[12,13]$.

\section{Modeling the Steel-Sheathed CFSF Buildings and Test Validation}

In fact, the dynamic behavior of the steel-sheathed CFSF structures is very complicated. The hysteresis behavior of this building is hardly accurate, simulated by traditional finite element software including ANSYS and ABAQUS, because larger deformation combining highly nonlinear behaviors may be leading to nonconvergence of these software. Besides, these software could not capture slipping behavior of the CFS walls. In recent years, a modeling method that simplifies a CFS wall as two nonlinear springs can be modeled by two-node link elements based on OpenSees software [30]. This method has been verified and proposed by many researchers. Pinching 04 material is usually used to simulate the hysteresis behavior of the twonode link element, and the hysteresis parameters of this material can be determined from tests. The hysteresis model of Pinching 04 is illustrated in Figure 2.

In this paper, the selected steel-sheathed CFSF buildings are modeled based on the simplified method, and the hysteresis parameters of the walls used in these buildings are generated from the shaking table tests conducted by Shamim and Rogers [13]. The analytic model of the wall along with the direction of earthquakes is depicted in Figure 3. 
TABLE 1: Wall configurations of the CFSF buildings.

\begin{tabular}{|c|c|c|c|c|c|c|}
\hline Building & $\begin{array}{c}\text { Sheathing thickness of } \\
\text { 1st story }(\mathrm{mm})\end{array}$ & $\begin{array}{l}\text { Fastener spacing of } \\
\text { 1st story }(\mathrm{mm})\end{array}$ & $\begin{array}{l}\text { Sheathing thickness of } \\
\text { 2nd story }(\mathrm{mm})\end{array}$ & $\begin{array}{l}\text { Fastener spacing of } \\
\text { 2nd story }(\mathrm{mm})\end{array}$ & $\begin{array}{l}\text { Grade of steel } \\
(1 \mathrm{st} / 2 \mathrm{nd}, \mathrm{MPa})\end{array}$ & $\begin{array}{l}\text { Rayleigh } \\
\text { damping }\end{array}$ \\
\hline S-1 & 0.46 & $50 / 300$ & 0.46 & $75 / 300$ & $345 / 345$ & $5.0 \%$ \\
\hline S-2 & 0.76 & $50 / 300$ & 0.76 & $150 / 300$ & $345 / 230$ & $6.0 \%$ \\
\hline S-3 & 0.76 & $50 / 300$ & 0.76 & $100 / 300$ & $345 / 230$ & $7.5 \%$ \\
\hline S-4 & 0.76 & $50 / 300$ & 0.76 & $75 / 300$ & $345 / 230$ & $6.5 \%$ \\
\hline
\end{tabular}

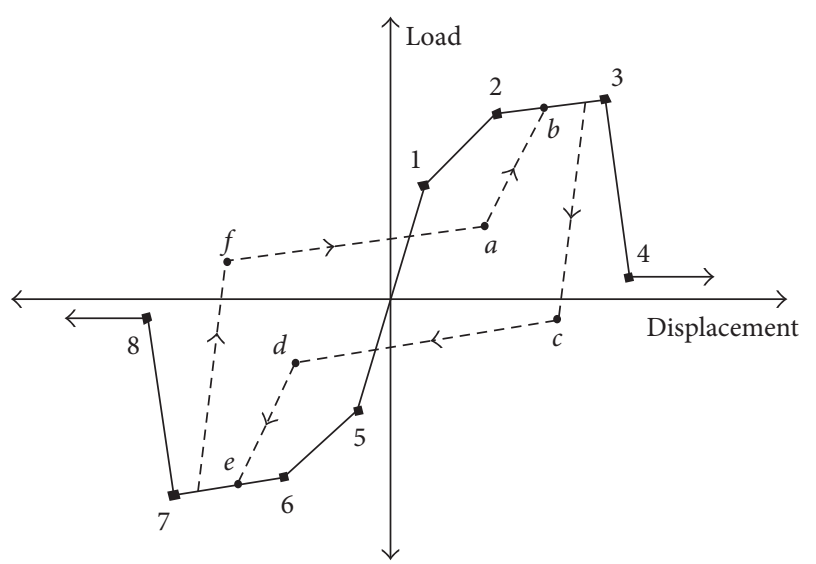

$$
\begin{array}{ll}
i=\left(e P d_{i}, e P f_{i}\right), i=1 \ldots 4 & b=\left(d_{\max }, f\left(d_{\max }\right)\right) \\
a=\left(r D i s p P . d_{\max }, r f o r c e P . f\left(d_{\max }\right)\right) & f=\left(*, \text { uforceP.ePf } f_{3}\right)
\end{array}
$$

Figure 2: Hysteresis model for Pinching 04 material.

In this analytic model, the C-studs are modeled as elastic truss, while the tracks and beams are modeled as rigid truss. The connections of the CFS components are modeled as simplified hinge nodes, as there is almost no bending moment transmitted in these connections. The floor and roof are modeled as rigid planes, and these planes are connected with the hinge nodes. The mass of the building is input at the center of these planes. In order to compute the P-delta behavior of these buildings, the gravity loads are considered of the nodes according to the tributary area of these nodes. The walls are modeled by two-node link elements, and Pinching 04 material of these elements is selected from the study of Shamim and Rogers [13]. In their studies, the uplift behaviors of the anchor rods and hold downs were modeled as linear springs, and the stiffness of these springs was determined as $17.6 \mathrm{kN} / \mathrm{mm}$ and $52 \mathrm{kN} / \mathrm{mm}$ for the first and the second story, respectively. According to the analytic models of the four buildings, the fundamental periods can be obtained as $0.52 \mathrm{~s}, 0.64 \mathrm{~s}, 0.49 \mathrm{~s}$, and $0.42 \mathrm{~s}$.

Four single-bay single-story steel-sheathed CFSF walls are selected from study of Shamim et al. [12, 13] to valid these analytic models. These walls were $1.22 \mathrm{~m}$ in width and $2.44 \mathrm{~m}$ in height, and their detailed configurations are listed in Table 2. The detailed information of these tested specimens can be found in the previous studies of Shamim et al. $[12,13]$. These walls were tested subjected to the Quebec ground motion record with different scaling factors; the Quebec ground motion is shown in Figure 4, and the scaling factors of these walls are listed in Table 2. The

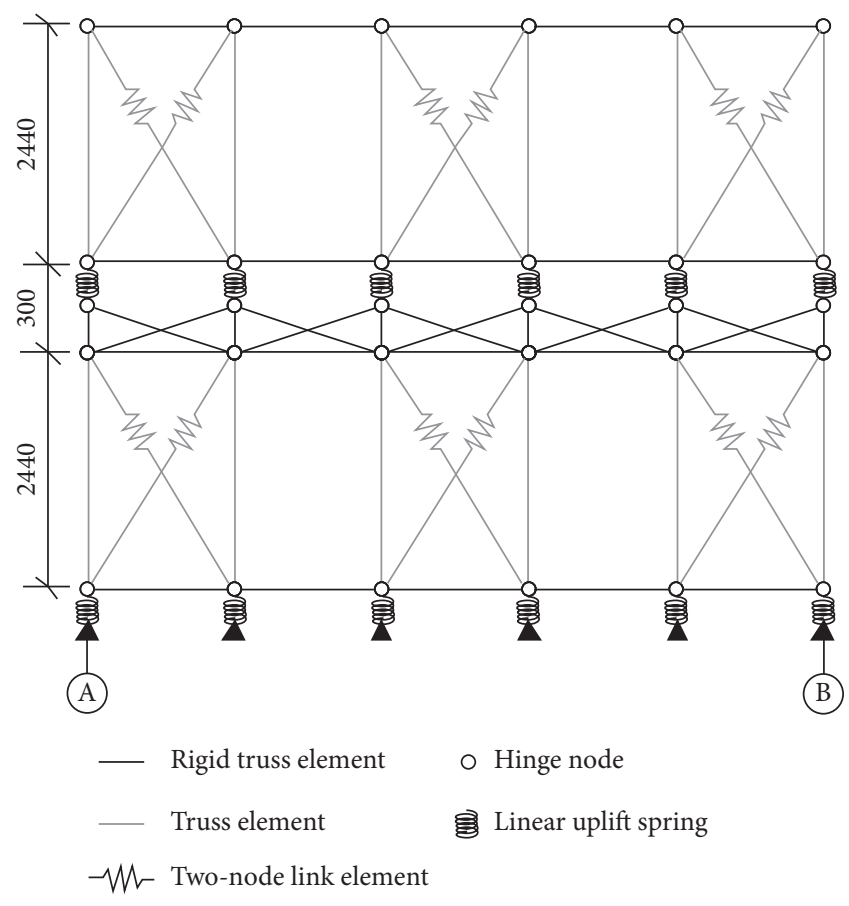

Figure 3: Analytic model of the walls from axial-A to axial-B.

computed drift ratio and strength time-history curves as well as the test results of these walls are depicted in Figures 5-8. It can be found that the maximum values of the drift ratio and strength computed from the analytic models are in good accordance with the maximum values of the test results, and the errors are less than $20 \%$.

\section{Fragility Analyses of These Steel-Sheathed CFSF Buildings}

4.1. Performance Limits Definition. In order to quantify the seismic damage of these steel-sheathed CFSF buildings, it is important to define a proper damage measure which can be used to describe the damage level of the buildings. Maximum story drift ratio (ISDA) is used in this paper as an index of structural damage addressing the proposition of FEMA 356 [31], and FEMA 356 defined three different performance limits to describe the damage level of structures. In recent years, such performance limits were defined for CFSF buildings by some researchers [27-29] according to quasi-static and shaking table tests, but they are still unknown for steel-sheathed CFSF buildings. Therefore, three performance limits of steel-sheathed CFSF buildings are defined in this paper, and they are described below. 
TABLE 2: Configurations of the tested single-bay single-story steel-sheathed CFSF walls.

\begin{tabular}{lccccc}
\hline Specimen & Sheathing thickness $(\mathrm{mm})$ & Fastener spacing $(\mathrm{mm})$ & Scaling factor & PGA $(\mathrm{g})$ & Rayleigh damping \\
\hline ST 1-a & 0.76 & $150 / 300$ & 2.8 & 0.70 & $5.0 \%$ \\
ST 1-b & 0.76 & $100 / 300$ & 3.5 & 0.88 & $6.0 \%$ \\
ST 1-c & 0.76 & $50 / 300$ & 4.0 & 1.00 & $7.5 \%$ \\
ST 1-d & 0.46 & $150 / 300$ & 1.8 & 0.45 & $6.5 \%$ \\
\hline
\end{tabular}

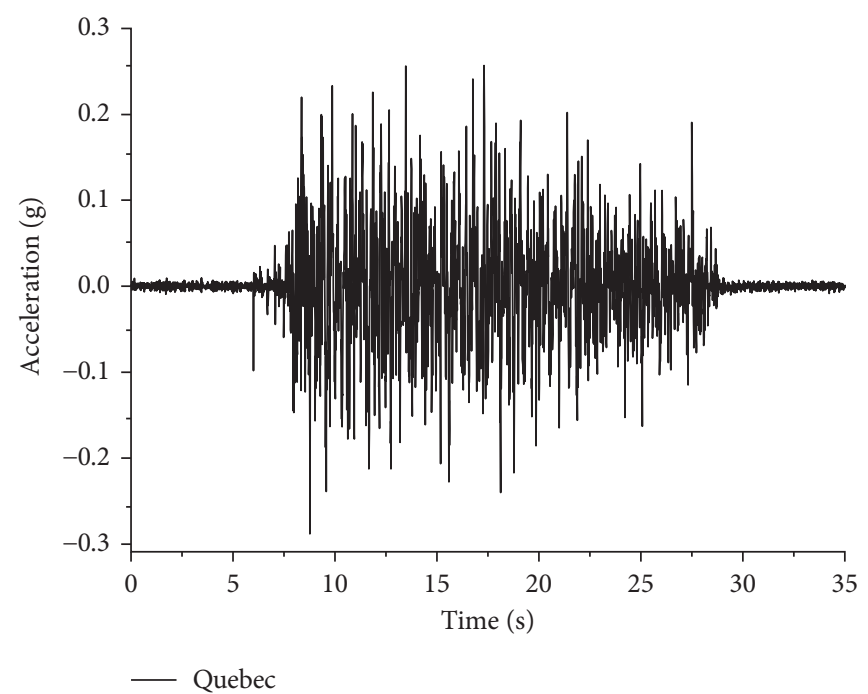

Figure 4: Ground motion of Quebec.

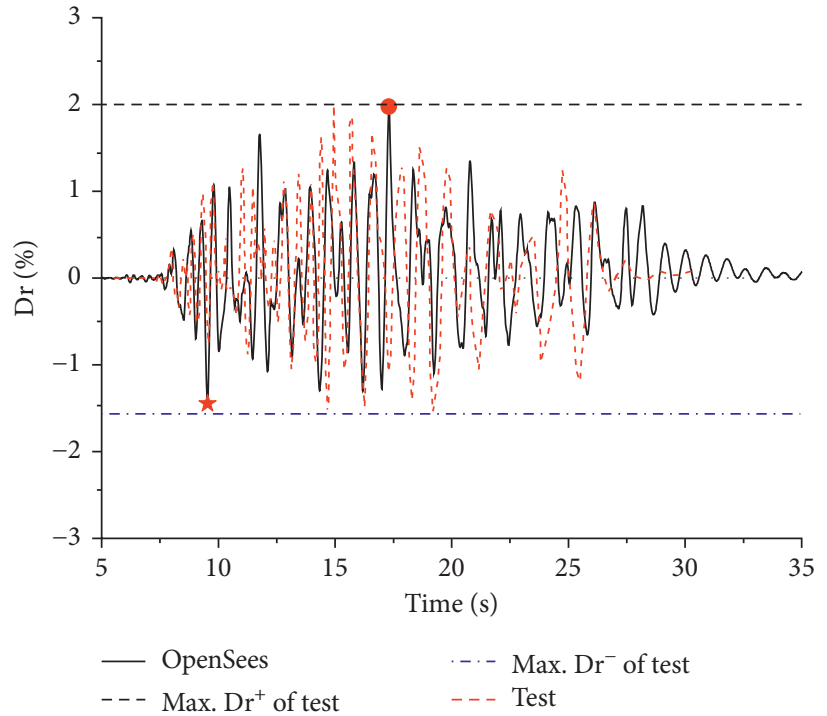

(a)

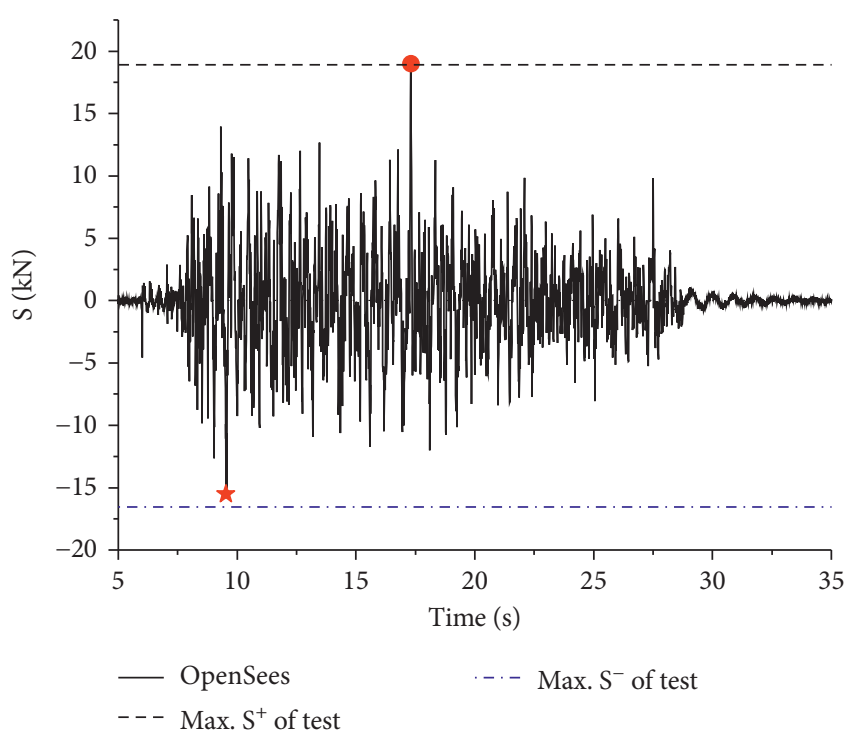

(b)

FIgURE 5: Comparison of analytic model and test for specimen ST 1-a. (a) Drift ratio. (b) Strength.

4.1.1. Immediate Occupancy (IO). The structure needs to be able to guarantee that the structural damage is negligible and nonstructural elements remain serviceable. This limit is reached if minor buckling appeared on the steel-sheathed CFS wall, or a tension field was formed along the diagonal of the wall.
4.1.2. Structural Damage (SD). The structural and nonstructural members of the structure are significantly damaged, but they can still be occupied. This limit is reached if siginificant buckling of steel sheathing and several boundary elements, screws pull out of the studs, 


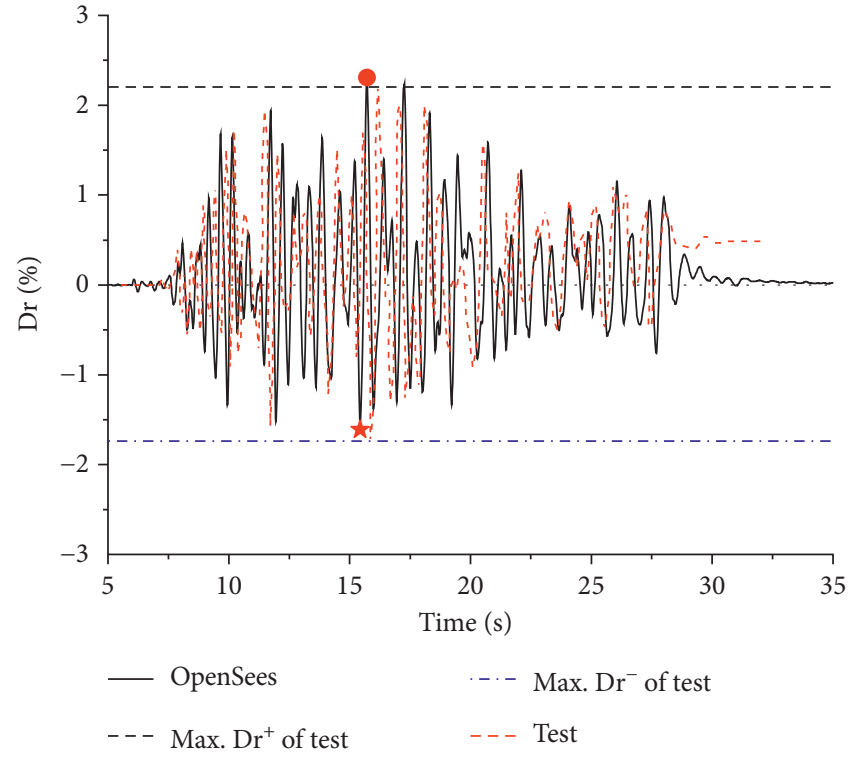

(a)

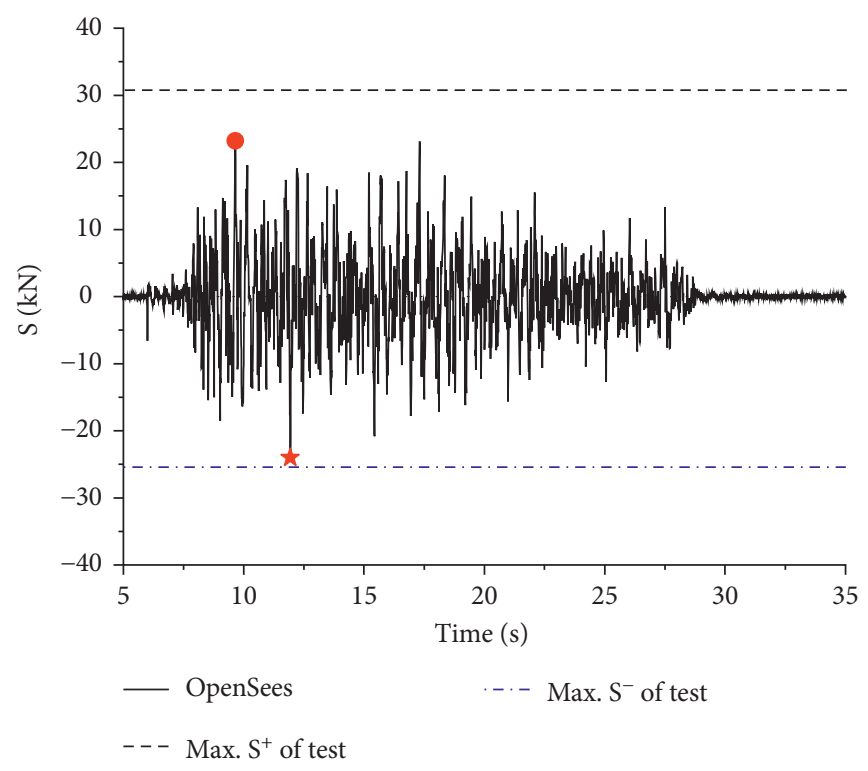

(b)

Figure 6: Comparison of analytic model and test for specimen ST 1-b. (a) Drift ratio. (b) Strength.

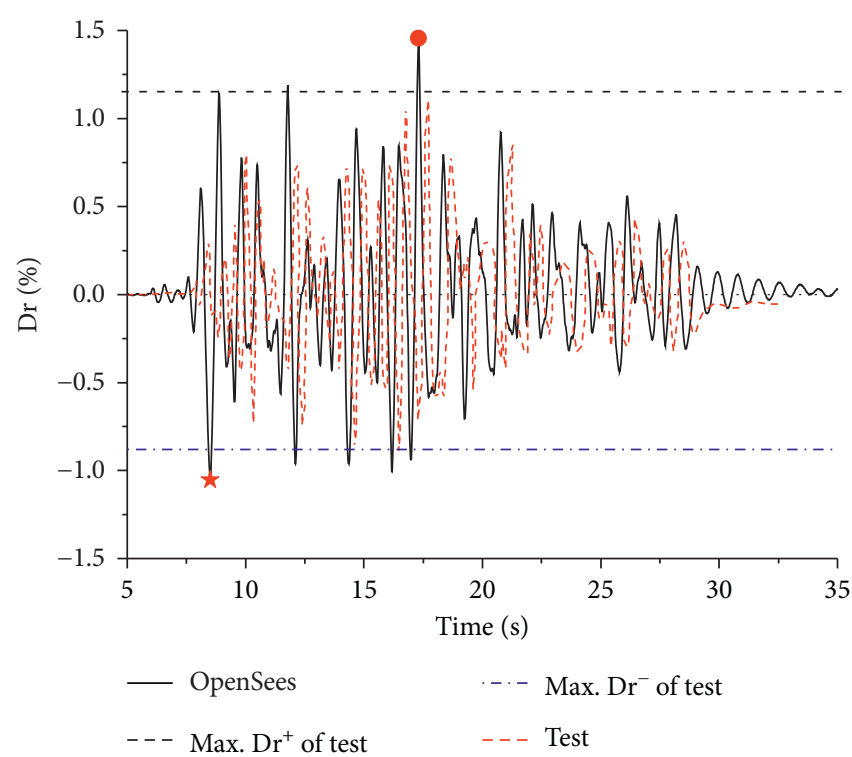

(a)

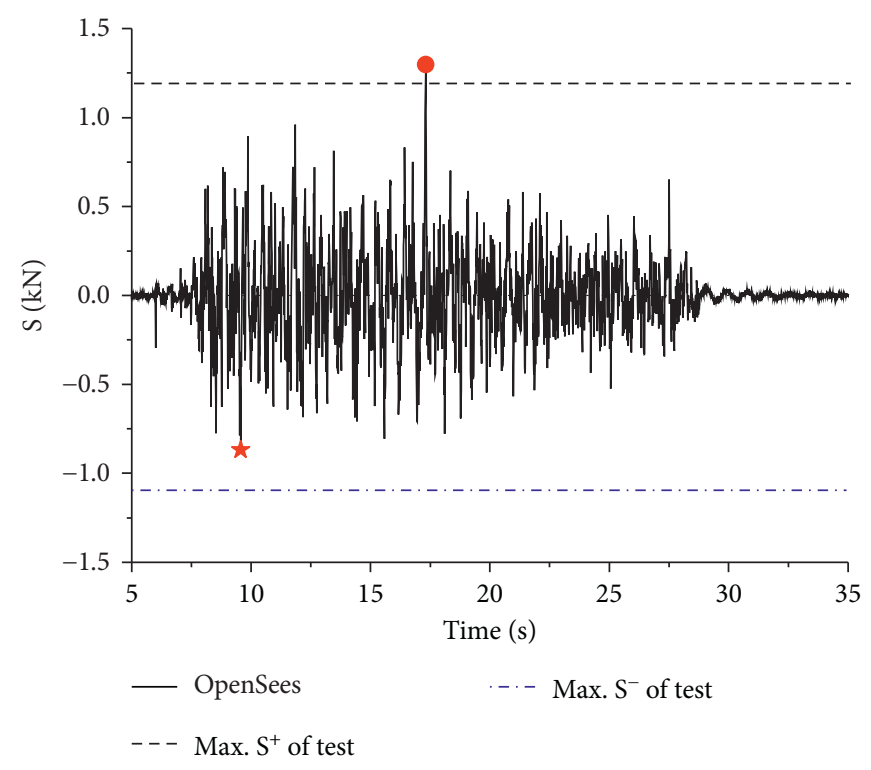

(b)

Figure 7: Comparison of analytic model and test for specimen ST 1-c. (a) Drift ratio. (b) Strength.

out-of-plate distortion of the stud flange or yield of some studs.

4.1.3. Collapse Prevention (CP). The structure is already unsafe to be occupied, and complete damage would be reached nearly. This limit is reached if the overall buckling of many steel-sheathed walls or a plenty of steel sheathings tore and CFS frames fractured, connections loosed, or sheathings sheared off.
In this paper, the story drift ratios of these three performance limits are defined as $1.0 \%, 2.0 \%$, and $4.0 \%$ for IO, $\mathrm{SD}$, and CP limits, respectively. Such values are determined through statistic analyses on 71 cyclic test specimens which could be found in the authors' previous study.

4.2. Earthquake Ground Motion Selection. Ground motions recorded from actual earthquakes are desired for seismic fragility analysis of building structures. In this paper, a suite 


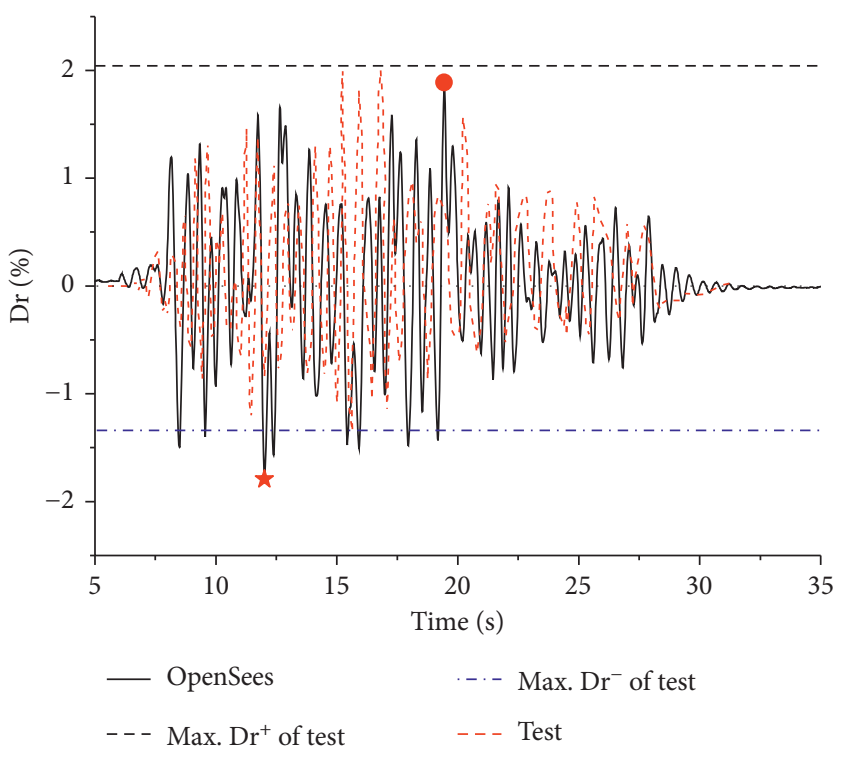

(a)

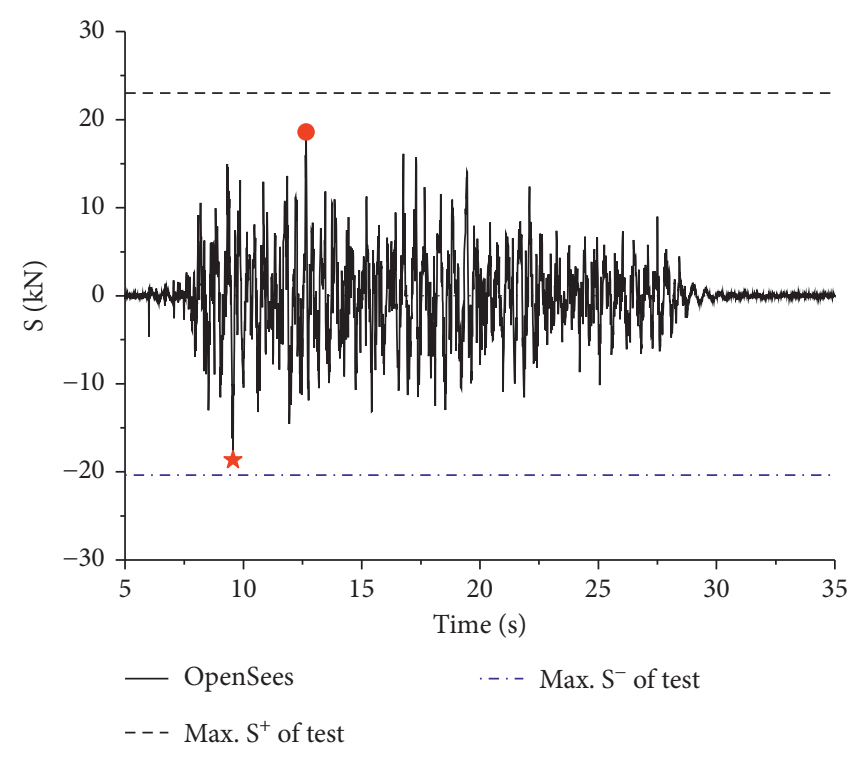

(b)

FIgURE 8: Comparison of analytic model and test for specimen ST 1-d. (a) Drift ratio. (b) Strength.

TABLE 3: Ground motions of LA 10\%/50 yr ensemble.

\begin{tabular}{|c|c|c|c|c|c|}
\hline No. & Record & Magnitude & Distance $(\mathrm{km})$ & Duration (sec) & PGA $\left(\mathrm{cm} / \mathrm{sec}^{2}\right)$ \\
\hline LA01 & Imperial Valley, 1940, El Centro & 6.9 & 10 & 39.38 & 452.03 \\
\hline LA02 & Imperial Valley, 1940, El Centro & 6.9 & 10 & 39.38 & 662.88 \\
\hline LA03 & Imperial Valley, 1979, Array \#05 & 6.5 & 4.1 & 39.38 & 386.04 \\
\hline LA04 & Imperial Valley, 1979, Array \#05 & 6.5 & 4.1 & 39.38 & 478.65 \\
\hline LA05 & Imperial Valley, 1979, Array \#06 & 6.5 & 1.2 & 39.08 & 295.69 \\
\hline LA06 & Imperial Valley, 1979, Array \#06 & 6.5 & 1.2 & 39.08 & 230.08 \\
\hline LA07 & Landers, 1992, Barstow & 7.3 & 36 & 79.98 & 412.98 \\
\hline LA08 & Landers, 1992, Barstow & 7.3 & 36 & 79.98 & 417.49 \\
\hline LA09 & Landers, 1992, Yermo & 7.3 & 25 & 79.98 & 509.7 \\
\hline LA10 & Landers, 1992, Yermo & 7.3 & 25 & 79.98 & 353.35 \\
\hline LA11 & Loma Prieta, 1989, Gilroy & 7 & 12 & 39.98 & 652.49 \\
\hline LA12 & Loma Prieta, 1989, Gilroy & 7 & 12 & 39.98 & 950.93 \\
\hline LA13 & Northridge, 1994, Newhall & 6.7 & 6.7 & 59.98 & 664.93 \\
\hline LA14 & Northridge, 1994, Newhall & 6.7 & 6.7 & 59.98 & 644.49 \\
\hline LA15 & Northridge, 1994, Rinaldi RS & 6.7 & 7.5 & 14.945 & 523.3 \\
\hline LA16 & Northridge, 1994, Rinaldi RS & 6.7 & 7.5 & 14.945 & 568.58 \\
\hline LA17 & Northridge, 1994, Sylmar & 6.7 & 6.4 & 59.98 & 558.43 \\
\hline LA18 & Northridge, 1994, Sylmar & 6.7 & 6.4 & 59.98 & 801.44 \\
\hline LA19 & North Palm Springs, 1986 & 6 & 6.7 & 59.98 & 999.43 \\
\hline LA20 & North Palm Springs, 1986 & 6 & 6.7 & 59.98 & 967.61 \\
\hline
\end{tabular}

of 20 ground motions is used in this study based on the SAC project for Los Angeles. These ground motions were determined with a probability of exceedance of $10 \%$ in 50 years. The detailed information of these records is listed in Table 3. Besides, the elastic acceleration spectrum of these records and their mean value are depicted in Figure 9 corresponding to $5 \%$ damping.
4.3. Determination of Fragility Parameters. The interstory drift ratio (ISDA) as a damage index to express the damage level of a whole structure, while the seismic intensity is used to express the hazard level of the input earthquake, and spectral acceleration at the fundamental period $S_{a}\left(T_{1}\right)$ of the building is commonly used as the seismic intensity. Based on the definition in previous studies [21-24, 32], fragility function 


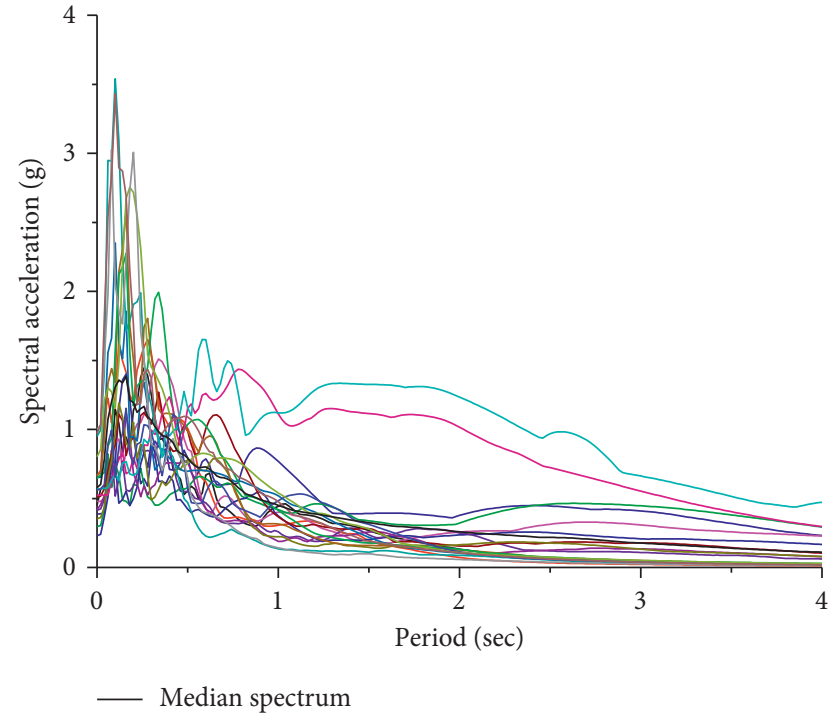

FIGURE 9: Responses spectra of SAC project ensemble for Los Angeles.

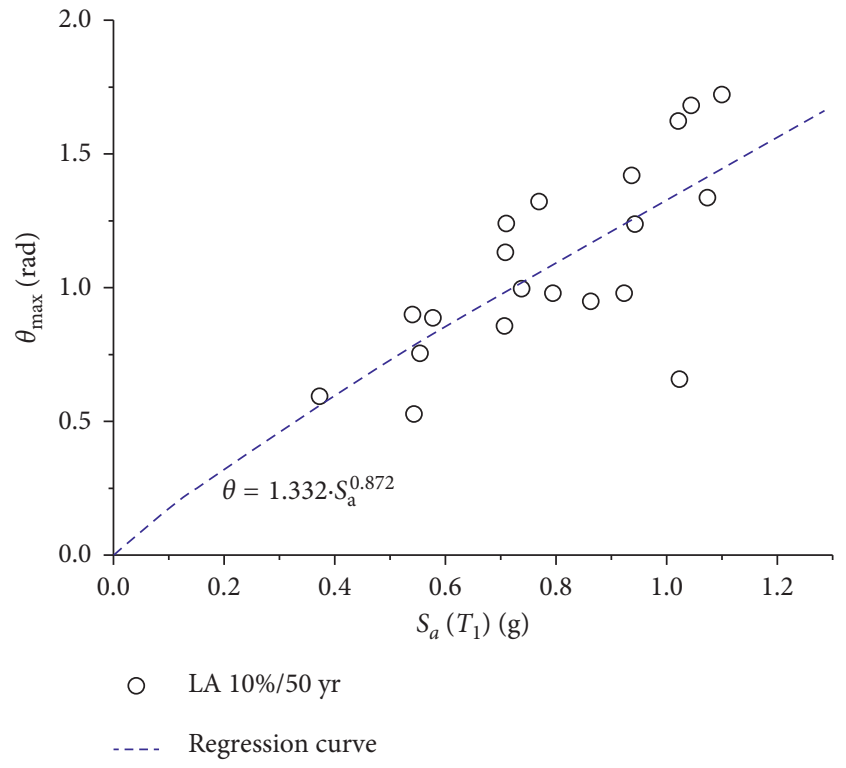

Figure 10: Seismic demands and regression curve of the building S-1.

can be described by a log-normal distribution, and the fragility parameters include the mean value and the standard deviation. The fragility function is

$$
F_{R}(x)=\Phi\left(\frac{\left(\ln x-\ln m_{R}\right)}{\beta_{R}}\right),
$$

where $\Phi()$ represents the standard normal probability integral, $x$ is the intensity of the ground motion (e.g., $S_{a}$ ), and $m_{R}$ and $\beta_{R}$ are the mean value and the logarithmic standard deviation, respectively.

To determine the logarithmic standard deviation $\beta_{R}$, the potential uncertainties associated with the steel-sheathed CFSF building should be considered and quantified, including aleatoric uncertainties (e.g., earthquakes, structural resistance,

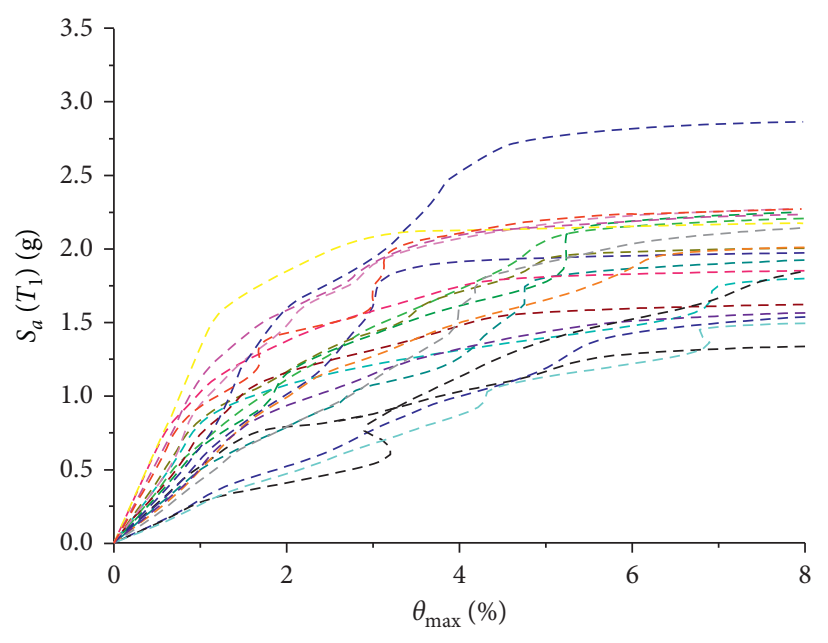

FIgURE 11: IDA curves of the building S-1 subjected to LA $10 \% / 50 \mathrm{yr}$.

TABLE 4: Fragility parameters of the CFSF buildings.

\begin{tabular}{lcccc}
\hline Building & $m_{R}(\mathrm{IO})$ & $m_{R}(\mathrm{SD})$ & $m_{R}(\mathrm{CP})$ & $\beta_{R}$ \\
\hline S-1 & 0.683 & 1.220 & 1.707 & 0.542 \\
S-2 & 0.476 & 1.078 & 1.505 & 0.546 \\
S-3 & 0.648 & 1.307 & 1.942 & 0.537 \\
S-4 & 0.839 & 1.554 & 2.281 & 0.529 \\
\hline
\end{tabular}

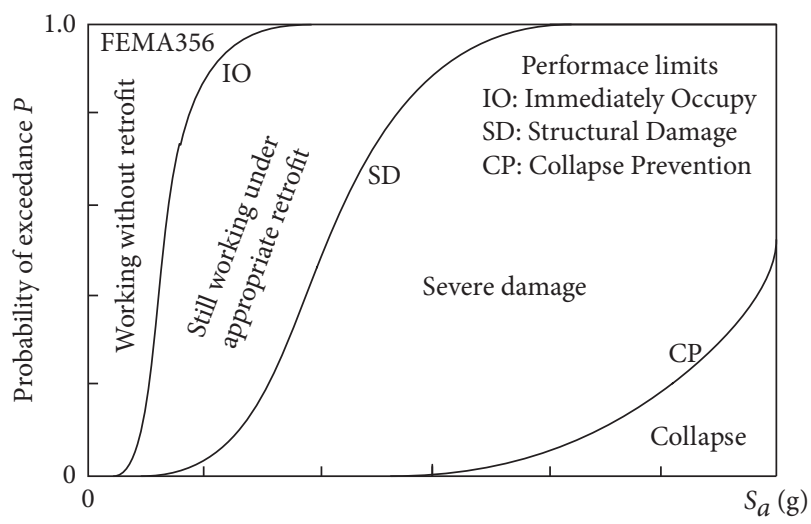

FIGURE 12: Diagram of fragility curves based on FEMA 356.

and defined performance limits) and epistemic uncertainty (e. g., modeling technologies). According to the proposition from previous studies [21, 22], the square-root-sum-ofsquares (SRSS) method is used to make a synthesis consideration of these uncertainties. The function is

$$
\beta_{R}=\sqrt{\beta_{r-r}^{2}+\beta_{C}^{2}+\beta_{r}^{2}+\beta_{m}^{2}}
$$

where $\beta_{r-r}$ is the deviation due to earthquakes, $\beta_{C}$ is the deviation due to the uncertainty in defining performance limits, $\beta_{r}$ is the deviation due to structural uncertainties, and $\beta_{m}$ is the epistemic uncertainty due to current structural modeling technologies. The deviations of $\beta_{C}$ and $\beta_{r}$ have been discussed and quantified in the authors' previous study, 


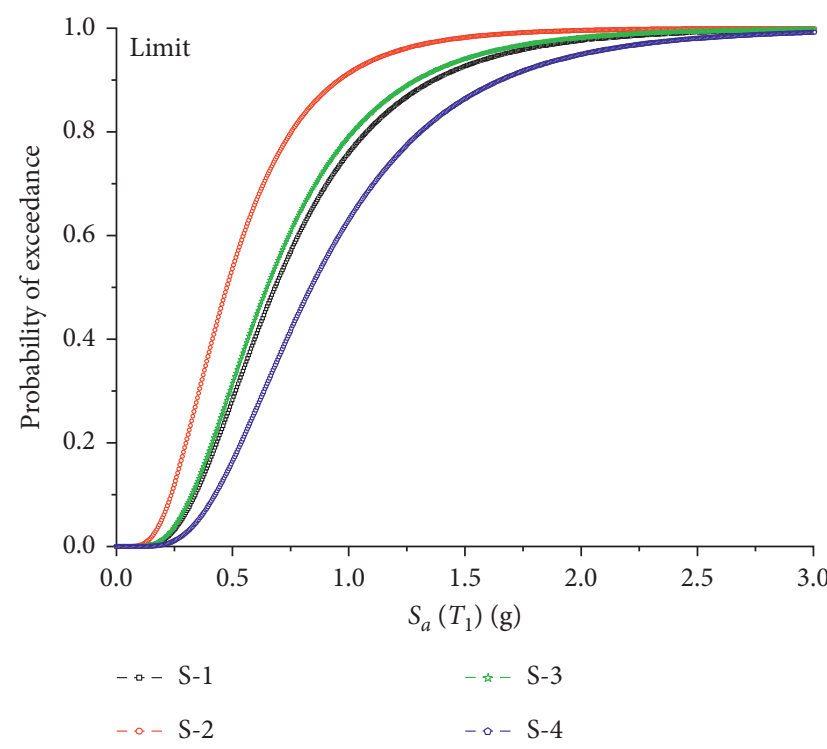

(a)

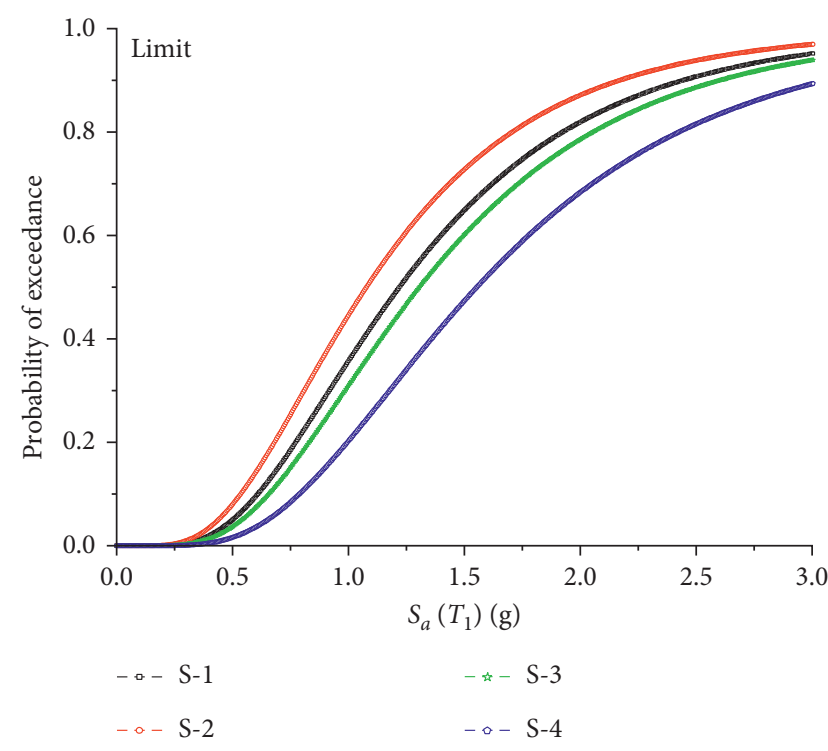

(b)

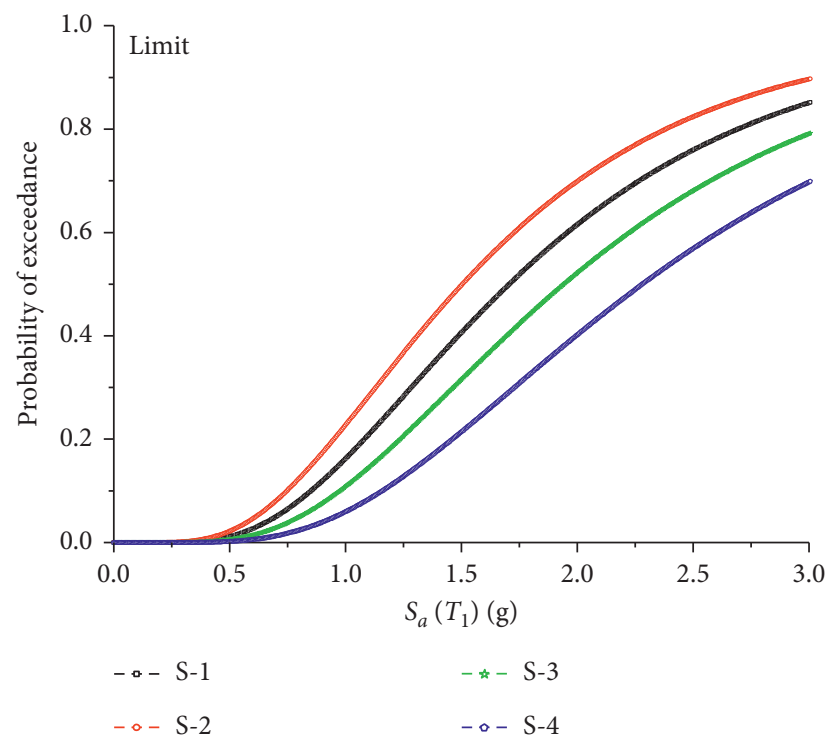

(c)

FIgURE 13: Fragility curves of the buildings S-1, S-2, S-3, and S-4. (a) IO, (b) SD, and (c) CP.

and a combination value of 0.41 was calculated according to the statistic analyses of the test specimens and the examples generated from the Latin hypercube sampling technique. $\beta_{m}$ determined as 0.2 for low-level modeling uncertainty is considered in this study.

The uncertainty of earthquakes can be considered as the uncertainty in seismic demand of the building $[21,32]$. To obtain the deviation due to earthquakes, $\beta_{r-r}$, it is important to determine the relationship between seismic intensity and structural demand. In this paper, the seismic intensity and structural demand are represented by the $S_{a}\left(T_{1}\right)$ and the maximum ISDA $\theta_{\max }$. The relation between the $\theta_{\max }$ of the steel-sheathed CFSF building and the $S_{a}\left(T_{1}\right)$ can be determined as

$$
\theta_{\max }=a S_{a}^{b} \varepsilon,
$$

where $a$ and $b$ are constants, and $\varepsilon$ is the random variable. It can be found that a special $\varepsilon$ can be calculated from each ground motion. The building S-1 is chosen to describe the calculating process of the $\beta_{r-r}$ and the results of $\theta_{\max }-S_{a}\left(T_{1}\right)$ of building S-1 are depicted in Figure 10. Besides, a regression curve is added to describe the relation between $\theta_{\max }$ and $S_{a}$ $\left(T_{1}\right)$ based on (2), as shown in Figure 10. It is recommended that the logarithmic standard deviation $\sigma_{\ln \varepsilon}$ can be used as the $\beta_{r-r}[21,32]$, and the value is $\sigma_{\ln \varepsilon}=0.293$ for building S-1.

To determine the mean value $m_{R}$ corresponding to each performance limit, incremental dynamic analysis (IDA) is proposed as an efficient method [32]. The IDA curves of the 


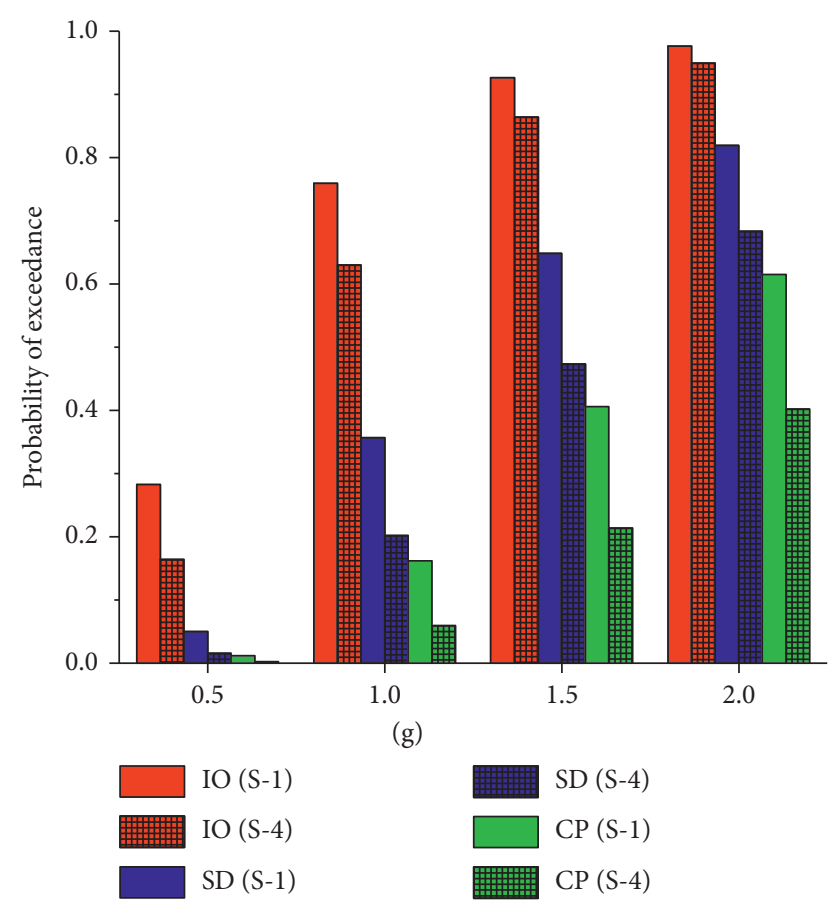

FIGURE 14: Impact of sheathing thickness on seismic fragility.

building S-1 are shown in Figure 11, subjected to 20 ground motions of LA $10 \% / 50 \mathrm{yr}$ ensemble. The fragility parameters of these buildings can be determined from these IDA curves, and they are listed in Table 4.

4.4. Fragility Curve Generation. The diagram of fragility curves associated with the performance limits defined in Section 4.1 is depicted in Figure 12. Three curves represent the seismic fragility of IO, SD, and CP limits, respectively. Four regions are divided according to the requirements of serviceability and safety of the building structures. According to the fragility parameters presented in Table 4, the fragility curves of these buildings are drawn in Figure 13.

To make comparisons of the impact of wall configurations (e.g., thickness of the steel sheathing and fastener spacing) on exceeding probability of the steel-sheathed CFSF buildings, samples are selected subjected to spectral accelerations of $0.5 \mathrm{~g}, 1.0 \mathrm{~g}, 1.5 \mathrm{~g}$, and $2.0 \mathrm{~g}$ for the analyzed buildings.

Figure 14 shows the impacts of sheathing thickness on exceeding probabilities of $\mathrm{IO}, \mathrm{SD}$, and $\mathrm{CP}$ limits. It can be found that the exceeding probabilities are generally decreased when the thickness of steel sheathing is enhanced from $0.46 \mathrm{~mm}$ to $0.76 \mathrm{~mm}$. The collapse probability of the building with $0.76 \mathrm{~mm}$ thickness of steel sheathing decreases more than $50 \%$ compared with the wall with $0.46 \mathrm{~mm}$ in thickness if it experiences earthquakes with spectral acceleration from $1.0 \mathrm{~g}$ to $1.5 \mathrm{~g}$. It is indicated that increasing the thickness of steel sheathings is an effective way to reduce the seismic losses.

Figure 15 shows the impact of fastener spacing on exceeding probabilities of some interested cases. The relation

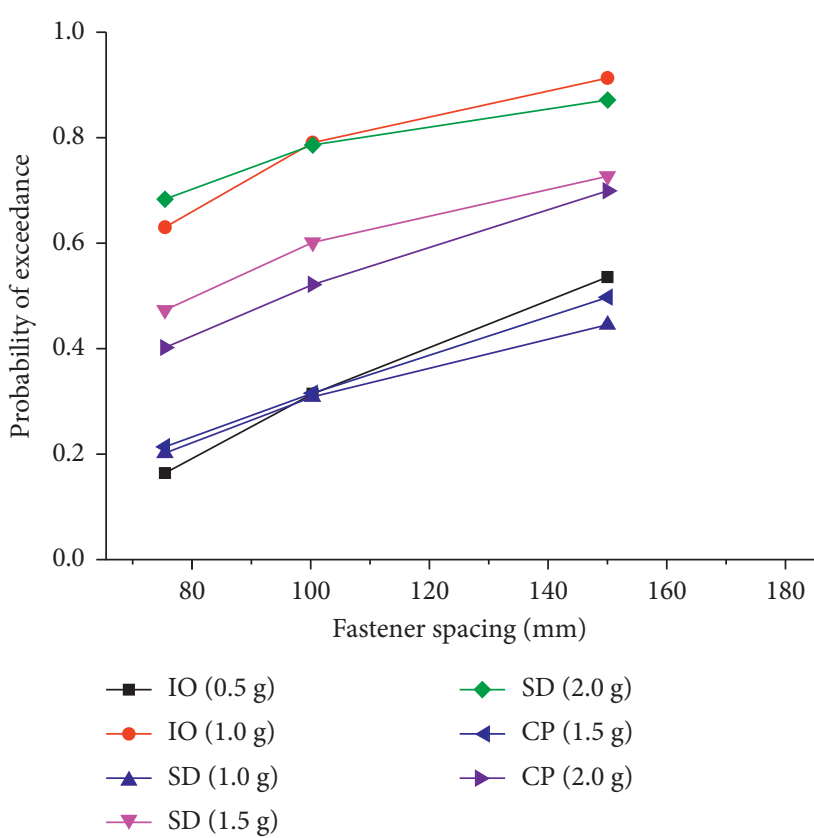

Figure 15: Impact of fastener spacing on seismic fragility.

between the exceeding probability and fastener spacing can be described as an approximately linear curve, and the slopes of these curves range from $0.25 \% / \mathrm{mm}$ to $0.50 \% / \mathrm{mm}$.

\section{Conclusions}

In this study, the impact of wall configurations on seismic fragility is investigated by four 2-story steel-sheathed CFSF buildings. Based on the shaking table tests on steel-sheathed CFSF walls $[12,13]$, an analytical model of these buildings is developed to conduct incremental dynamic analysis. Then, the fragility curves are developed to describe the probability corresponding to each performance limit of the buildings subjected to a given seismic intensity. The results show the following:

(1) The thickness of steel sheathing shows significant impact on the seismic performance of the CFSF building. The fragility of the building with $0.76 \mathrm{~mm}$ thick steel sheathing is lower than that of the building with $0.46 \mathrm{~mm}$ thick steel sheathing. Such improvements seem more obvious for the CP limit. The collapse probability of the building with $0.76 \mathrm{~mm}$ thickn steel sheathing decreases more than 50\% compared with the wall with $0.46 \mathrm{~mm}$ thick steel sheathing if it experiences earthquakes with spectral acceleration ranging from $1.0 \mathrm{~g}$ to $1.5 \mathrm{~g}$.

(2) In addition to the thickness of steel sheathing, the fastener spacing of the wall is also showing significant impact on seismic fragility of the building. The fragility of the building decreases with decreasing the fastener spacing. It is also found that the relation between the exceeding probability and fastener spacing can be described as an approximately linear curve, and the slope ranges from $0.25 \% / \mathrm{mm}$ to $0.50 \% / \mathrm{mm}$. 


\section{Conflicts of Interest}

The authors declare that there are no conflicts of interest regarding the publication of this paper.

\section{Acknowledgments}

This research is sponsored by the National Key Program Foundation of China (51538002), the Priority Academic Program Development of Jiangsu Higher Education Institutions (CE02-2-32), and the Priority Academic Program Development of Jiangsu Higher Education Institutions, Scientific Innovation Research Foundation of Jiangsu, China (KYLX15_0090). The authors thank Dr. Shamim for providing the data of ground motions used in the shaking table tests.

\section{References}

[1] J. Ye, L. Jiang, and X. Wang, "Seismic failure mechanism of reinforced cold-formed steel shear wall based on structural vulnerability analysis," Applied Sciences, vol. 7, no. 2, p. 182, 2017.

[2] P. Liu, K. D. Peterman, and B. W. Schafer, "Impact of construction details on OSB-sheathed cold-formed steel framed shear walls," Journal of Constructional Steel Research, vol. 101, no. 10, pp. 114-123, 2014.

[3] M. Gerami and M. Lotfi, "Analytical analysis of seismic behavior of cold-formed steel frames with strap brace and sheathing plates," Advances in Civil Engineering, vol. 2014, Article ID 535120, 22 pages, 2014.

[4] M. Zeynalian and H. R. Ronagh, "Seismic performance of cold formed steel walls sheathed by fibre-cement board panels," Journal of Constructional Steel Research, vol. 107, no. 4, pp. 1-11, 2015.

[5] W. Mowrtage, "Cyclic lateral load behavior of CFS walls sheathed with different materials," Thin-Walled Structures, vol. 96, no. 11, pp. 328-336, 2015.

[6] J. Ye, X. Wang, H. Jia, and M. Zhao, "Cyclic performance of cold-formed steel shear walls sheathed with double-layer wallboards on both sides," Thin-Walled Structures, vol. 92, no. 3, pp. 146-159, 2015.

[7] C. Yu, "Shear resistance of cold-formed steel framed shear walls with $0.686 \mathrm{~mm}, 0.762 \mathrm{~mm}$, and $0.838 \mathrm{~mm}$ steel sheet sheathing," Engineering Structures, vol. 32, no. 6, pp. 15221529, 2010.

[8] C. Yu and Y. Chen, "Detailing recommendations for $1.83 \mathrm{~mm}$ wide cold-formed steel shear walls with steel sheathing," Journal of Constructional Steel Research, vol. 67, no. 1, pp. 93-101, 2011.

[9] C. Ong-Tone and C. A. Rogers, Tests and Evaluation of ColdFormed Steel Frame/Steel Sheathed Shear Walls, Research Report, Department of Civil Engineering \& Applied Mechanics, McGill University, Montreal, Canada, 2009.

[10] N. Balh and C. A. Rogers, Development of Seismic Design Provisions for Steel Sheathed Shear Walls, Research Report, Department of Civil Engineering \& Applied Mechanics, McGill University, Montreal, Canada, 2010.

[11] N. Balh, J. DaBreo, C. Ong-Tone, K. El-Saloussy, C. Yu, and C. A. Rogers, "Design of steel sheathed cold-formed steel framed shear walls," Thin-Walled Structures, vol. 75, pp. 7686, 2014.

[12] I. Shamim, J. DaBreo, and C. A. Rogers, "Dynamic testing of single- and double-story steel-sheathed cold-formed steel- framed shear walls," Journal of Structural Engineering, vol. 139, no. 5, pp. 807-817, 2013.

[13] I. Shamim and C. A. Rogers, "Steel sheathed/CFS framed shear walls under dynamic loading: numerical modelling and calibration," Thin-Walled Structures, vol. 71, pp. 57-71, 2013.

[14] I. Shamim and C. A. Rogers, "Numerical evaluation: AISI S400 steel-sheathed CFS framed shear wall seismic design method," Thin-Walled Structures, vol. 95, pp. 48-59, 2015.

[15] A. Shakibanasab, N. K. A. Attari, and M. Salari, "A statistical and experimental investigation into the accuracy of capacity reduction factor for cold-formed steel shear walls with steel sheathing," Thin-walled Structures, vol. 77, pp. 56-66, 2014.

[16] N. K. A. Attari, S. Alizadeh, and S. Hadidi, "Investigation of CFS shear walls with one and two-sided steel sheeting," Journal of Constructional Steel Research, vol. 122, pp. 292-307, 2016.

[17] M. R. Javaheri-Tafti, H. R. Ronagh, F. Behnamfar, and P. Memarzadeh, "An experimental investigation on the seismic behavior of cold-formed steel walls sheathed by thin steel plates," Thin-Walled Structures, vol. 80, pp. 66-79, 2014.

[18] S. Mohebbi, R. Mirghaderi, F. Farahbod, and A. B. Sabbagh, "Experimental work on single and double-sided steel sheathed cold-formed steel shear walls for seismic actions," ThinWalled Structures, vol. 91, pp. 50-62, 2015.

[19] S. E. Niari, B. Rafezy, and K. Abedi, "Seismic behavior of steel sheathed cold-formed steel shear wall: experimental investigation and numerical modeling," Thin-Walled Structures, vol. 96, pp. 337-347, 2015.

[20] American Iron and Steel Institute (AISI), North American Standard of Cold-Formed Steel Framing-Lateral Design, AISI S400, American Iron and Steel Institute, Washington, USA, 2015.

[21] K. Porter, R. Kennedy, and R. Bachman, "Creating fragility functions for performance-based earthquake engineering," Earthquake Spectra, vol. 23, no. 2, pp. 471-489, 2007.

[22] J. Park, P. Towashiraporn, J. I. Craig, and B. J. Goodno, "Seismic fragility analysis of low-rise unreinforced masonry structures," Engineering Structures, vol. 31, no. 1, pp. 125-137, 2009.

[23] G. Castellazzi, C. Gentilini, and L. Nobile, "Seismic vulnerability assessment of a historical church limit analysis and nonlinear finite element analysis," Advances in Civil Engineering, vol. 2013, Article ID 517454, 12 pages, 2013.

[24] Y. Hu, J. H. Zhao, and L. Q. Jiang, "Seismic risk assessment of steel frames equipped with steel panel walls," Structural Design of Tall and Special Buildings, vol. 26, no. 10, p. e1368, 2017.

[25] K. D. Peterman, M. J. J. Stehman, R. L. Madsen, S. G. Buonopane, N. Nakata, and B. W. Schafer, "Experimental seismic responses of a full-scale cold-formed steel-framed building. I: system-level response," Journal of Structural Engineering, vol. 142, no. 12, p. 04016127, 2016.

[26] K. D. Peterman, M. J. J. Stehman, R. L. Madsen, S. G. Buonopane, N. Nakata, and B. W. Schafer, "Experimental seismic responses of a full-scale cold-formed steelframed building. II: subsystem-level response," Journal of Structural Engineering, vol. 142, no. 12, p. 04016128, 2016.

[27] X. Wang, E. Pantoli, T. C. Hutchinson et al., "Seismic performance of cold-formed steel wall systems in a full-scale building," Journal of Structural Engineering, vol. 141, no. 10, p. 04015014, 2015.

[28] C. Jenkins, S. Soroushian, E. Rahmanishamsi, and E. M. Maragakis, "Experimental fragility analysis of cold-formed steel-framed partition wall systems," Thin-Walled Structures, vol. 103, no. 6, pp. 115-127, 2016. 
[29] R. Retamales, R. Davies, G. Mosqueda, and A. Filiatrault, "Experimental seismic fragility of cold-formed steel framed gypsum partition walls," Journal of Structural Engineering, vol. 139 , no. 8, pp. 1285-1293, 2013.

[30] PEER, Open System for Earthquake Engineering Simulation, Pacific Earthquake Engineering Research Center, University of California, Berkley, CA, USA, 2006.

[31] FEMA 356, NEHRP Guidelines for the Seismic Rehabilitation of Buildings, Federal Emergency Management Agency, Washington, D.C., USA, 2002.

[32] C. A. Cornell, F. Jalayer, R. O. Hamburger, and D. A. Foutch, "Probabilistic basis for 2000 SAC Federal Emergency Management Agency steel moment frame guidelines," Journal of Structural Engineering, vol. 128, no. 4, pp. 526-533, 2002. 


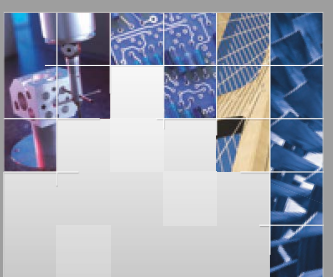

\section{Enfincering}
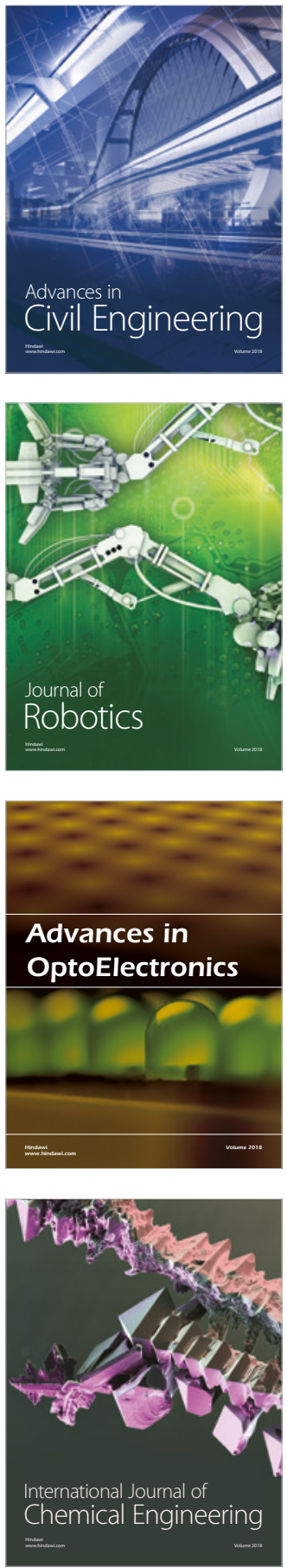

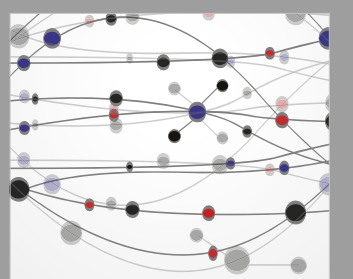

\section{Rotating \\ Machinery}

The Scientific World Journal

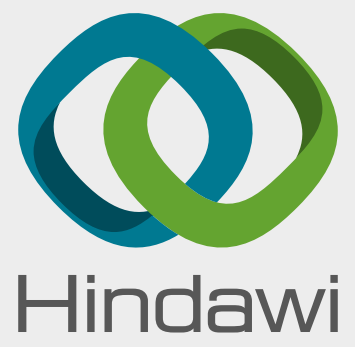

Submit your manuscripts at

www.hindawi.com
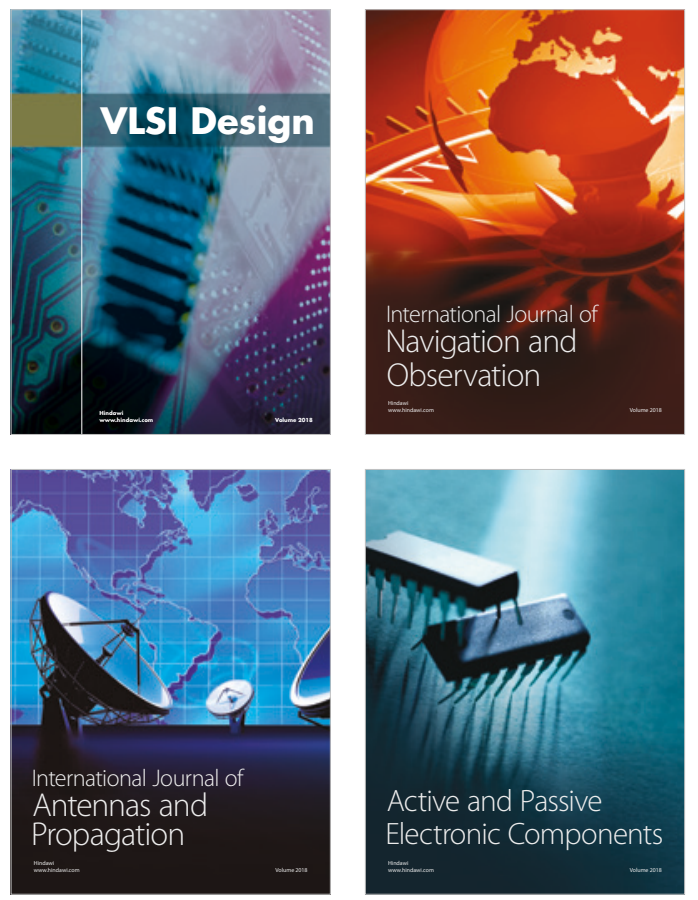
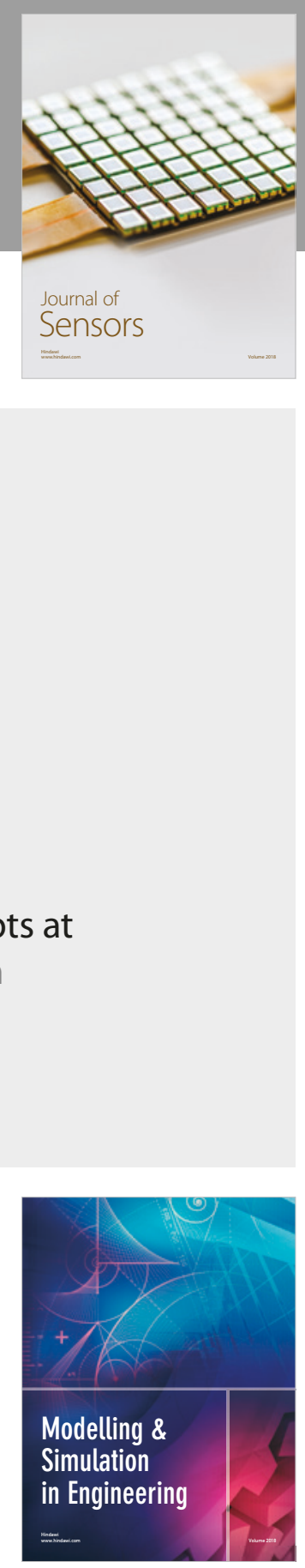

\section{Advances \\ Multimedia}
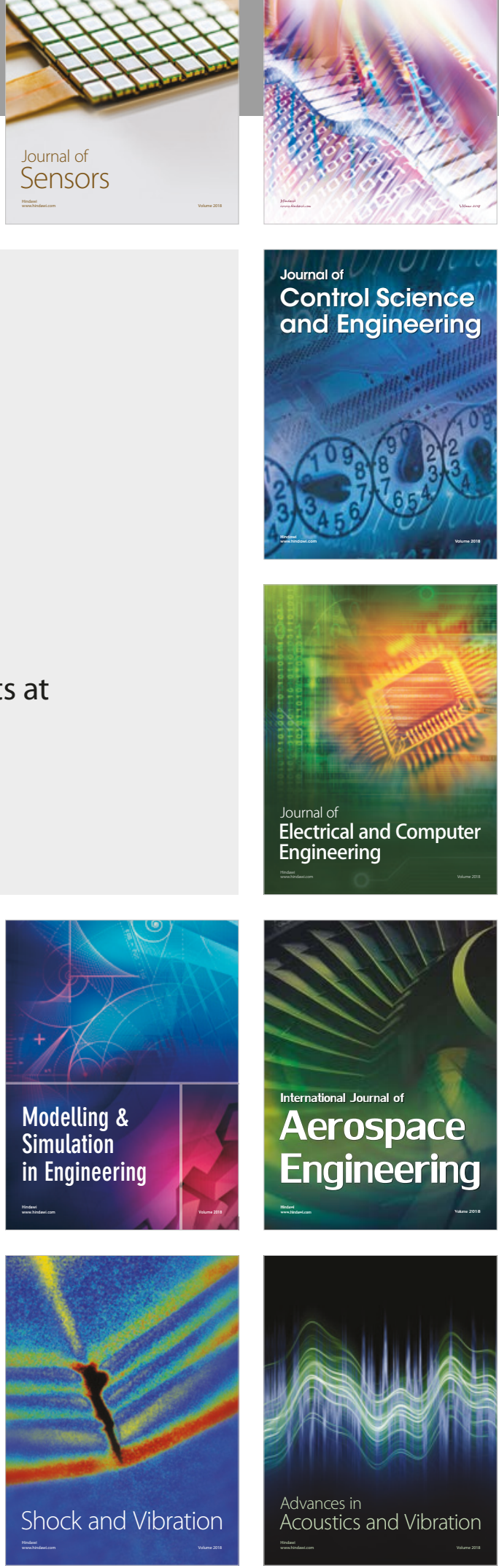